\title{
A Synthesis towards the Construct of Job Performance
}

\author{
Ramawickrama, J. ${ }^{1,2}$, H. H. D. N. P. Opatha ${ }^{1} \&$ PushpaKumari, M. D. ${ }^{1}$ \\ ${ }^{1}$ Faculty of Management Studies and Commerce, University of Sri Jayewardenepura, Sri Lanka \\ ${ }^{2}$ Faculty of Management and Finance, University of Ruhuna, Matara, Sri Lanka \\ Correspondence: Ramawickrama, J., Faculty of Management Studies and Commerce, University of Sri \\ Jayewardenepura, Sri Lanka; Faculty of Management and Finance, University of Ruhuna, Matara, Sri Lanka.
}

Received: July 4, 2017

Accepted: July 25, 2017

Online Published: September 7, 2017

doi:10.5539/ibr.v10n10p66

URL: https://doi.org/10.5539/ibr.v10n10p66

\begin{abstract}
Job performance is highly relevant for organizations and individuals alike. Individual Job performance is the behavioural outcome of an employee which points out that the employee is showing positive attitudes towards his or her organization. Job performance is differently defined and measured in different disciplines in different ways. The main purpose of this paper is to define and to review theoretically and empirically the concept of job performance, measurement dimensions of job performance and empirical findings for measurement dimensions of job performance with reference to the various professions in service oriented organizations. As a desk research, this study reviewed literature regarding job performance and its dynamic nature, compared and analyzed dimensions (taxonomies) related to job performance, created a new definition and explained the importance of job performance adding novelty to the existing literature and provided suggestions for further studies.
\end{abstract}

Keywords: human resource, job performance, service sector

\section{Introduction}

Employee is the crucial one among the other resources in an organization. The success or failure of the organization depends upon the level of contribution given by individuals who are employed in different careers in an organization. In 1920, job performance was simply mentioned as quantity and quality of the output of each employee who is working in an organization. But, in the present scenario employees do much more than traditionally included in their job descriptions. Otley (1999) categorized performance into twofold including organizational performance and job performance. Organizational performance is the major concern of managers as it indicates success of an organization. It considers how well and how far an organization has carried out its activities within a certain period of time. Simply it means that how successful the organization is within a period of time considered. According to Otley (1999), the performance of an organization depends upon the performance of employees and other factors such as the environment, the culture, leadership style and the work environment of the organization etc. The entire value of the individual outcome causes the organizational performance. It seems that the job performance is the smallest unit of the overall achievement of an organization. Therefore, job performance should be an active determinant in achieving the target, goal, mission and vision of an organization stated in the strategic planning process. Borman and Brush (1993) discussed job performance as both direct and indirect forms of employee contribution towards the organizational objectives. Lawler, Mohrman, and Ledford (1992) stated that organizations have started programs such as employee involvement, job enrichment, total quality management, autonomous team work, skill-based pay, and gain sharing plans for the enhancement of competitive advantage in a global economy. The goal of above programs was to increase firm performance by affecting employee behaviours on the job such as taking on increasing responsibility, encouraging employees to change the way they work, and actively contributing to the accomplishment of organizational objectives. Researchers have used alternative names for job performance including "Employee Performance", "Work Performance", "Individual Work Performance" etc. The main objective of this paper is to create a new synthesis to the existing knowledge of job performance revealed by different researchers in the world. Further, it attempts to achieve the following specific objectives:

1. To describe the meaning of job performance reflected from the existing definitions given by different authors.

2. To know whether the concept of job performance is dynamic or not in its nature and explain why. 
3. To find out whether job performance is a unidimensional concept or a multidimensional concept.

4. To identify the dimensions of job performance and determine the most frequently used ones based on existing literature.

5. To reveal whether there are diverse dimensions of job performance in relation to different professions.

6. To explain why job performance is very important.

\section{Method}

This paper discusses theoretical background of job performance including diverse definitions, nature, dimensions of job performance, importance and empirical findings of different dimensions of job performance which represent different professions in service sector organizations. Therefore, this paper is based on literature review. Archival method is more important for methodological review of existing literature (Tranfield, Denyer \& Smart, 2003). In 2013 Sekaran and Bougie advised that academic books and journals are, in general, the most useful sources of information. Hence, published information over the past years in relevant books and refereed journals was utilized for reviewing literature.

\section{Literature Review: Job Performance}

\subsection{Definitions of Job Performance}

The following Exhibit 1 shows how authors defined the construct of job performance.

Exhibit 1. Definitions of Job Performance

\begin{tabular}{|c|c|c|}
\hline Year & Author & Definition of Job Performance \\
\hline 1974 & Porter and Lawler & A function of individual ability, skills and effort in a given situation. \\
\hline 1984 & Bernardin and Beatty & $\begin{array}{l}\text { The record of outcomes produced by a specified job function or activity during a } \\
\text { specified time period. }\end{array}$ \\
\hline 1986 & Hunter & The single result of an employee's work. \\
\hline 1990 & Campbell & Behaviours or actions those are relevant to the goals of the organization. \\
\hline 1993 & Borman and Motowidlo & $\begin{array}{l}\text { Three important features are highlighted as follows: } \\
\text { i. Work performance should be defined in terms of behaviour rather than } \\
\text { results, } \\
\text { ii. Work performance includes only those behaviours that are relevant to the } \\
\text { organization's goals, } \\
\text { iii. Work performance is a multidimensional concept. }\end{array}$ \\
\hline 1998 & Ferris et al. & $\begin{array}{l}\text { Employee's job performance depends on or is a consequence of some combination of } \\
\text { ability, effort and opportunity. }\end{array}$ \\
\hline 1998 & Bernardin and Russell & $\begin{array}{l}\text { The record of outcomes produced on a specified job function or activity during a } \\
\text { specified time period. }\end{array}$ \\
\hline 2000 & Viswesvaran and Ones & $\begin{array}{l}\text { Scalable actions, behaviour and outcomes that employees engage in or bring about that } \\
\text { are linked with and contribute to organizational goals. }\end{array}$ \\
\hline 2002 & Mathis and Jackson & Contribution of employees to the organization. \\
\hline 2007 & Griffin & The sum of behaviours of employees. \\
\hline 2008 & Pushpakumari & The performance in terms of effort extended to the \\
\hline 2009 & Stewardt and Brown & The contribution that individuals make to the organization that employs them. \\
\hline 2015 & Opatha & $\begin{array}{l}\text { An employee's job performance is the extent to which duties and responsibilities have } \\
\text { been carried out. Two major criteria of measuring job performance are quantity of } \\
\text { work and quality of work. }\end{array}$ \\
\hline
\end{tabular}

(Source: based on literature)

According to these different definitions, at the very beginning Porter and Lawler (1974) considered that job performance is a function of individual ability, skills and effort in a given situation. Others added several highlighted elements to this concept and some considered it as an individual behaviour, closely linked with organizational goals. Murphy (1989) explained that job performance should be defined in terms of behaviour rather than results. Campbell et al. (1990) mentioned that one attribute, one outcome or one factor cannot be labeled as job performance. Hence, it should be a multidimensional construct.

\subsection{Dynamic Nature of Job Performance}

Due to the changing nature of work and organizations, individual work performance has taken a ne wer face from traditional views of individual work performance (Ilgen \& Pulakos, 1999). In 1995 Howard, as cited in Griffin et al. (2007) discussed two of the major changes; increasing independence and the uncertainty of work system. Campbell et al. (1990) and Murphy and Jackson (1999) stated the necessity of modern measures and they mentioned; "Early approaches to work performance did not account for the full range of behaviours that contribute to effectiveness when systems are uncertain and interdependent". Sonnentag and Frese (2001) 
highlighted that individual performance is not stable overtime. Variability in an individual's performance overtime reflects on two reasons. They are: 1 . Learning process and other long-term changes, 2 . Temporary changes in performance. As per, they explained that the nature of job performance is a purely personal related concept which may vary from different types of perspectives faced by individuals. Three types of perspectives of performance were mentioned based on the performance theory. They are: 1. Individual differences perspective, 2. Situational perspective and 3. Performance regulation perspective.

The individual differences perspective focuses on performance differences between individuals. According to individuals' personal capacities including personality, cognitive ability, motivation, and professional experiences may become an impact on job performance. On the other hand, some performance improvement programs such as exploring to specific experiences, training programs enable to enhance job performance of individuals.

The situational perspective refers to the factors in the individuals' environment that stimulate and support or hinder performance. It means that "which situations do individuals perform best?" Job characteristics, role stressor, situational constrains may affect the individual job performance. As a result, new job designing activities can be implemented due to its dynamic nature of job performance.

The performance regulation perspective takes a different look from the other two perspectives. This perspective focuses on the performance process itself and conceptualizes it as an action process. However, this perspective considers organizational level activities for the enhancement of job performance including goal setting, training and job designing, behaviour modification, improvement of action process, feedback intervention etc. Accordingly, job performance can be changed and improved through right identification of its dynamic nature.

Though it is discussed as separated perspectives, researchers often combined two or more of these approaches together to explain employee performance. For example, Barrick and Mount, (1993), suggest a linkage between individual differences and situational perspective. Further, Waldman (1994) also explained a model of performance in relation to individual differences perspective and the situational perspective. According to Waldman (1994), he assumes that both personal factors (individual difference variables) and system factors (situational variables) have an effect on job performance."

\subsection{Job Performance as a Unidimensional Concept or Multi-Dimensional Concept}

As stated above, job performance is not a concrete construct in nature. According to Ghiselli (1956), Campbell (1990), Austin and Villanova (1992), Campbell, McCloy, Oppler and Sager (1993), as cited in Hunt (1996), "Job performance is often treated as a unidimensional construct despite a variety of theories and empirical evidence suggesting that it is multidimensional." Campbell (1990) as cited in Johnson and Meade (2010), mentioned that majority of researchers noted that job performance is inherently multidimensional. Hunt (1996) mentioned "the persistence tendency to treat job performance as unidimensional may be due in part to the lack of adequate, empirically developed and tested taxonomies that clearly illustrate different dimensions of job performance." Hence, following part of the discussion is based on how different authors categorized dimensions for measuring job performance theoretically as well as empirically.

\subsection{Dimensions of Job Performance Based on Different Authors}

Burtt (1926) and Viteles (1932), as cited in Viswesvaran (2001), have considered both the organizational and individual perspective of job performance for assessment purpose. As a result, both organizational records (objective evaluation) and subjective (individual) e valuation measures have been categorized. The objective measures considered the result based evaluation and subjective measures considered judgment based on personal traits. According to the nature the subjective measures are difficult to decide than the objective measures.

In1944, Toops argued a distinction between accuracy (quality or lack of errors) and quantity (volume of output) as one of the earliest attempts for hypothesizing job performance. As a result, Toops has scheduled measures of job performance into five including 1. Unit of production, 2. Quality of work, 3. Tenure, 4. Supervisory, and 5. Leadership abilities. In 1957 Wherry as cited in Viswesvaran (2001), itemized six dimensions for job performance including 1. Output, 2. Quality, 3. Lost time, 4. Turnover, 5. Training time or promotion ability, and 6. Satisfaction. Moreover, In 1976 Smith distinguished between hard criteria and soft criteria. While the hard criteria were the organizational records, the soft criteria were the subjective evaluation.

In 1980 Schmidt, as cited in Viswesvaran (2001), classified organizational records into direct measures and indirect measures based on the production and personal data. Direct measures of production data included the number of units produced, quality of products in terms of scrap material produced and so forth. Such organizational records are considered more 'Objective' evaluation. Indirect measures depend on human judgment. Individual job performances are considered 'Subjective' evaluation that can be either ratings or 
rankings such as tenure, tardiness, lateness, accidents, filling grievances, promotion rates and absence etc.

In 1986 Hunter described characteristics that can predict future job performance including 1. Past performance of related jobs, 2. Job knowledge, 3. Psychomotor skills, 4. Cognitive abilities, 5. Social skills and Job related attitudes such as Need for enthusiasm, Stress and control, Achievement. Bernardin and Beatty (1984) also assessed job performance in terms of six dimensions. They are: 1. Quality, 2. Quantity, 3. Timeliness, 4. Cost-effectiveness, 5. Need for supervision and 6. Interpersonal impact.

Generally, performance data were categorized into two groups including judgmental and nonjudgmental measures by Landy and Farr in 1983. Although judgmental methods are more widely used, objective performance indices (for example: production output, scrap rates and time to complete a task) have been useful measures of performance for routine, manual jobs since the 1940s (Rothe, 1951; Rothe \& Nye, 1961) and these measures have received renewed attention more recently (Bass \& Turner, 1973). Further, other nonjudgmental measures that do not directly measure performance but would provide information on the general health of the organization (for example: grievances, accidents, absenteeism and turnover were considered). Moreover, the following discussion is based on dimensions of job performance which have been used by previous researchers for their studies and few of them are summarized in chronological order.

In 1986 Brief and Motowidlo declared about Pro-social organizational behaviour and the most pro-active behaviours include personal initiatives. Consequently, employees show personal initiatives when their behaviours fit an organization mission, when their goals have a long-term focus, and when they are capable of finding a solution for the challenging situation. The easy way to identify the forms of pro-social behaviour is observing the acts of members such as helping, sharing, donating, and volunteering. According to them, "pro-social organizational behaviour is:

1. performed by a member of an organization,

2. directed towards an individual, group or organization with whom he or she interacts while carrying out his or her organizational role, and

3. performed with the intention of promoting the welfare of the individual, group or organization towards which it is directed" (Brief and Motowidlo (1986), as cited in Hazzi \& Maldaon in 2012).

Thirteen types of pro-social organizational behaviours were specified by Brief and Motowidlo in 1986. They are:

1. Assisting co-workers with job-related matters

2. Showing leniency

3. Providing service/product to consumers in organizationally consistent ways

4. Providing service/product to consumers in organizationally inconsistent ways

5. Helping consumers with personal matters unrelated to organizational services/products

6. Complying with organizational values, policies and regulations

7. Suggesting procedural, administrative or organizational improvements

8. Objecting to improper directives, procedures or policies

9. Putting forth extra effort on the job

10. Volunteering for additional assignments

11. Staying with the organization despite temporary hardships

12. Requesting the organization favourably

13. Assisting co-workers with personal matters

In 1998 Organ classified two types of contextual performance behaviours including:

1. Organizational citizenship behaviour and

2. Pro-social behaviour

Accordingly, he has mentioned that there are five widely accepted components of organizational citizenship behaviour including 1. Altruism, 2. Conscientiousness, 3. Civic virtue, 4. Courtesy, and 5. Sportsmanship. They are in detail as follows:

1. Altruism- an employee's tendency to help other co-workers in the firm with their work (helping behaviour). 
2. Conscientiousness- an employee's decision to do the job by compliance to organizational norms and the need to surpass formal requirements

3. Civic virtue - when an employee participates responsibly in matters pertaining to the organization's political life.

4. Courtesy- prevention of problems arising from work relationship and treating other co-workers with respect.

5. Sportsmanship- an employee's reaction to trivial matters by not complaining and maintaining a positive attitude.

In 1989 Murphy elaborated four dimensions of job performance such as:

1. Task oriented behaviour: accomplishment of duties and responsibilities of someone's job.

2. Interpersonally oriented behaviour: represented by any interaction the focal employee has with other employees. This can be task related and non-task related behaviours including cooperating, communicating, exchanging job related information.

3. Down-time behaviour: employees engage in during their free time either at work or off-site.(for examples. outside behaviour that causes lateness, absences)

4. Destructive or hazardous behaviour: Non-compliance with rules, violence on job, theft and other behaviours counterproductive to the goals of the organization.

Campbell et al. (1990) proposed a general latent structure of job performance with eight performance components. They are:

1. Job- specific task behaviours: behaviours that an individual undertakes as a part of a job

2. Non-job-specific task behaviours: do not pertain only to a particular job

3. Written and oral communication behaviours: include formal and informal oral and written presentations to various audiences in many different jobs in the work force

4. Demonstrating effort: consistency or perseverance and intensity of the individuals to complete the task

5. Maintaining personal discipline: individual would be expected to be in good standing with the law

6. Facilitating peer and team performance: acting as a good role model, coaching, giving advice or helping to maintain group goals

7. Supervision or leadership position: responsible for meeting out rewards and punishments. These aspects of performance occur in a face to face manner

8. Management or administration: setting organizational goal or responding external stimuli to assist a group in achieving goals of organization.

In 1993, Borman and Brush discussed employee performance based on two basic dimensions including:

1. In-role work performance

2. Extra-role performance

In-role work performance involves activities that are related to employees' formal role requirements (Borman \& Motowidlo, 1993). According to Brown (1996), generally it is believed that job involvement, by positively affecting employees' motivation and effort, leads to higher level of in-role job performance. Williams and Anderson (1991) described "In-role performance as the work behaviour that is related to duties and responsibilities that are formally specified in the employment contract."

Extra role performance involves certain behaviours of employees which are not part of their formal job requirements as they cannot be prescribed in advance for a given job but they help in the smooth functioning of the organization as a social system (Bateman \& Organ, 1983). This type of behaviour is called as organizational citizenship behaviour and it can be divided into two categories.

The first is the 'organization-oriented citizenship behaviour', for example, adhere to the informal rules that aim at maintaining the work orders, when one cannot go to work, he or she will ask for leave in advance etc. The other category is 'individual-oriented organizational citizenship behaviour'. For this category, the direct purpose of the subjective behaviour is to benefit the individual, but it indirectly contributes to the organization by this way and examples are help absent colleagues to complete the work, interpersonal assistance. The organization-oriented citizenship behaviour is labeled common obedience or compliance, on the other hand 
individual-oriented organizational citizenship behaviour is labeled altruism.

In1993 Borman and Motowidlo also considered performance as a multi-dimensional concept through a twofold categorization:

\section{Task Performance}

\section{Contextual Performance}

Task performance is "the proficiency with which job incumbents perform activities that are formally recognized as part of their jobs; activities that contribute to the organization's technical core either directly by implementing a part of its technical process, or indirectly by providing it with needed materials or services" (Borman \& Motowidlo, 1993). They believed that the contribution should be included in task performance; direct (for example; in the case of production workers) or indirect (for example; in the case of managers or staff personnel). It is highlighted two central features of task performance that are formally recognized as part of the job and contribute to the technical core. Murphy (1989) defined task performance as "the accomplishment of tasks within an incumbent's job description." Further, in recent years paid attention to specific aspects of task performance such as innovation and customer oriented behaviour become increasingly important as organizations put greater emphasis on customer service (Anderson \& King, 1993; Bowen \& Weldman, 1999; as cited in Sonnentag \& Frese, 2001).

Contextual performance is also not a single set of uniform behaviours. Van Dyne and Lepine (1998) mentioned it as a multi-dimensional concept. Moreover, Motowidlo and Van Scotter (1994), Borman and Motowidlo (1997), Hattrup, and O' Connell, and Wingate (1998), as cited in Sonnentagand Frese (2001), mentioned "Contextual performance is predicted by other individual variables, not only task performance. Abilities and skills tend to predict task performance while personality and related factors tend to predict contextual performance."

Not only having the above basic category of task and contextual behaviour of job performance, but also Hunt (1996) proposed "Generic work behaviour" as taxonomies of job performance. It is defined as behaviour that contributes to the performance of virtually any job independent of technical job roles. Eight specific dimensions of generic work performance have been suggested through a specific analysis of employee behaviours in retail settings. These dimensions were; 1 . Industriousness, 2. Thoroughness, 3. Schedule Flexibility, 4. Attendance, 5. Off-task behaviour, 6. Unruliness, 7. Theft and 8. Drug misuse.

In 1996 Viswesvaran, Ones, and Schmidt suggested that context of job performance includes ten dimensions. They have categorized ten dimensions using a content analysis and conceptual grouping including 1 . Productivity, 2. Effort, 3. Job knowledge, 4. Interpersonal competence, 5. Administrative competence, 6. Quality, 7. Communication competence, 8. Leadership, 9. Compliance with authority, and 10. Overall job performance. Afterward, in the early 2000s Viswesvaran and ones have categorized job performance into three broad dimensions including 1. Task performance, 2. Organizational citizenship performance, and 3. Counterproductive work behavior (Koopmans et al., 2011).

Pulakos et al. (2000) paid attention towards the dynamic nature of the environment and discussed another perspective of job performance. They highlighted the necessity of the concept of "Adaptive performance". Different authors have applied different names for adaptive performance such as Neal and Hesketh (1999), Pulakos et al. (2000) referred as "Adaptive performance"; Murphy and Jackson (1999) "Role flexibility". London and Mone (1999), as cited in Pulakos et al. (2000) used the term "Proficiency of integrating new learning experiences" Pulakos et al. (2000) have conducted a wide literature review and factor analysis. They have suggested an eight dimensional taxonomy for adaptive performance including:

1. Handling emergencies or crisis situation

2. Handling work stress

3. Solving problems creatively

4. Dealing with uncertain and unpredictable work situation

5. Learning work tasks, technologies and procedures

6. Demonstrating interpersonal adaptability

7. Demonstrating cultural adaptability

8. Demonstrating physical oriented adaptability

The idea presented by Pulakos and co-workers suggested that more empirical research is needed for increased importance of adaptive performance. Having a special attention on adaptive performance, Stokes (2008) has 
done a convergent and predictive validity of adaptive performance. A Venn diagram has been created to review the amalgamated view of the leading job performance model. Figure 1shows this diagram and it mentions the nature of relationship among each dimension of job performance which has been mentioned by different scholars.

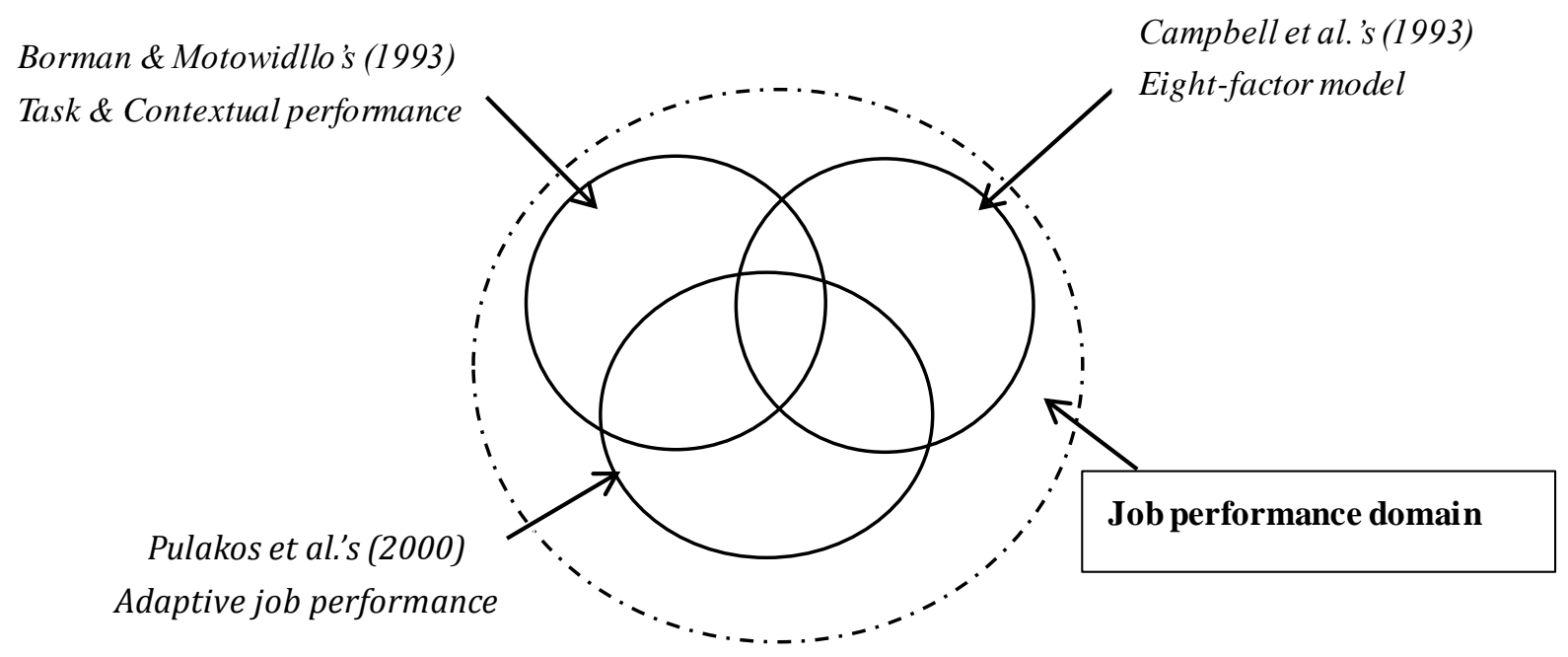

Figure 1. Amalgamated view of the leading job performance models

(Source: Stokes, (2008). "Adaptive Performance: An Examination of Convergent and Predictive Validity")

The Figure 1 includes three types of job performance domains. It is considered job performance an integrated model of three models introduced by Campbell et al. (1990), Borman and Motowidlo (1993), and Pulakos et al. (2000). Thus, it is too difficult to bring job performance clearly into a common category due to its subjective nature. It also provides proper evidence that there is no any reciprocal categorization of measurement dimensions of job performance. In accordance with Campbell (1990), Borman and Motowidlo (1993), it is mentioned that due to lack of unifying theoretical framework, job and non-job dimensions have been introduced by scholars. Hence, the above Venn diagram is important to identify the integrative nature among the different dimensions of job performance. However, the above figure emphasizes that there are no precisely defined categories for measuring job performance. One can use job performance dimensions as separate domains or a combination of more than one category together.

Rotundo and Sackett (2002) discussed three main performance dimensions under the general performance factors including:

1. Task performance

2. Citizenship performance

3. Counterproductive performance

Task performance occurs when employees perform actions that transform raw materials into goods and services. It is the most obvious form of contribution to an organization, because it represents behaviours that directly produce goods and services. In most organizations, a very large portion of employee effort is spent on task performance. Hence task performance is the "proficiency with which job incumbents perform activities that are formally organized as part of their jobs; activities that contribute to the organization's technical core either directly by implementing a part of its technical process, or indirectly by providing it with needed material or services" (Borman \& Motowidlo, 1993). Task performances are divided into two parts: 1.Declarative knowledge, and 2. Procedural knowledge and skills (McCloy, Campbell \& Cudeck, 1994). Declarative knowledge understands of what needs to be done to perform certain tasks. Under the procedural knowledge and skill, it is concerned the ability to perform the prescribed tasks. Therefore, the employee must know 'what to do' and 'how to do' the activities to perform an assigned task.

Citizenship Performance contributes to organization by building a positive organizational environment. This concept considers 'behaviours of a discretionary nature that are not part of employees' formal role requirements, but nevertheless promote the effective functioning of the organization" (Organ, 1988). Therefore, employees are good citizens when they willingly go beyond minimum expectations to cooperate and help others, for example, 
volunteering to take on tasks that are not part of one's job.

Two major parts of citizenship behaviour are Organizational citizenship behaviour and Interpersonal citizenship behaviour (Scott \& Judge, 2009). Employees engage in organizational citizenship behaviour when they do such things as protecting the organization's property, giving advance notice when unable to come to work, and following informal rules that help maintain order etc. The interpersonal citizenship behaviour is positive employee actions aimed at helping specific co-workers succeed. Such behaviours include taking time to listen to co-workers' problem, passing along information to peers, and helping people who have been absent etc.

Counterproductive performance is harmful to the organizations and its employees. Rotundo, et al. (2002) mentioned this as "it is non-task behaviour that has negative consequences for organizations and as well as employees". Due to such a circumstance, lower productivity is to be created (Dunlop \& Lee, 2004). Counterproductive behaviour is also directed towards either the organization or specific individuals.

According to Robinson and Bennett (1995) these two dimensions are categorized into four distinct categories including production deviance, property deviance, political deviance and personal aggression.

While the production deviance and property deviance actions are directed towards organization, other two are directed towards interpersonal behaviour. Production deviance is considered as harmful employee actions aimed at reducing the speed and accuracy of production process such as taking unauthorized breaks, intentionally working slowly, wasting company resources etc. However, the more serious is property deviance which includes actions that destroy the assets of an organization such as sabotage of equipment, misuse of expense accounts or steal materials and products. Further, they defined the political deviance as harmful actions that are designed to harm the performance and career of the other employees such as gossiping about co-workers, showing favoritism, and competing with others in non-beneficial ways. However, more serious form of counterproductive behaviour directed toward individuals is personal aggression which is presented by unsympathetic acts including violence and sexual harassment.

In 2011 Koopmans et al. have proposed a conceptual framework of individual work performance as a systematic review. They had understood four theoretical dimensions including:

1. Task performance,

2. Contextual performance,

3. Adaptive performance,

4. Counterproductive work behaviour

This study used 123 indicators for the measurement process of the construct. The following sub areas show how they defined each dimension and used indicators to measure these dimensions.

Task Performance was defined as central job tasks which are assigned to employees. Accordingly, Koopmans and others included job knowledge, work quantity, work quality, keeping knowledge up-to-data, job skills, working accurately and neatly, planning and organizing, decision making, administration, solving problem, oral and written communication, monitoring and controlling resources under the category of task performance.

Contextual performance was referred to employee behaviour that supports the organizational, social and psychological environment in which the central tasks are performed. They included effort, initiative, attention to duty, enthusiasm, resourcefulness, motivation, dedication, persistence, proactivity, creativity, corporation with and helping others, communication, politeness, interpersonal relations and organizational commitment.

Adaptive performance was referred to an employee's proficiency in adapting to changes in a work system or work roles. It included adjusting goals and plans according to situation, generating new innovative ideas, learning new tasks and technologies, understanding other groups or cultures, being flexible and open minded towards others, showing resilience, quick analysis, remaining calm, and acting appropriately.

Counterproductive work behavior was considered as harmful to the well-being of the organization. It included off-task behaviour, presenteeism, too many or longer breaks, absenteeism, doing task incorrectly, complaining, tardiness, accidents, insulting or gossiping about co-workers, fighting or arguing with co-workers, misusing privileges, theft, dis-regarding safety, aggression, and substance abuse.

Koopmans et al. (2011) have conducted their study for determining constructs of individual job performance in relation to different research fields, including occupational health, psychology and management. Therefore, it can be considered as a massive study and their heuristic framework is generalizable to all types of job. They have collected many of job performance related dimensions which have been used by previous scholars and all those 
dimensions have been categorized into above four. Further, they have proposed to conduct empirical studies for future researchers associating with different types of jobs. As a result of the above findings, taxonomies that have been used in earlier stage up to the present were reviewed. It shows that different scholars have used different measures for measuring purpose of job performance due to its complexity.

The Following Table 1 demonstrates widely used job performance dimensions that have been referred by selected authors in literature from 1986 to up to the present day.

Table 1. Dimensions of job performance used by previous authors

\begin{tabular}{|c|c|c|c|c|c|c|c|c|c|c|c|c|c|c|c|c|c|}
\hline \multirow[t]{2}{*}{ No } & \multirow[b]{2}{*}{ Dimensions of Job Performance } & \multicolumn{16}{|c|}{ Author/s in Chronological Order (Year)* } \\
\hline & & 1 & 2 & 3 & 4 & 5 & 6 & 7 & 8 & 9 & 10 & 11 & 12 & 13 & 14 & Total & $\%$ \\
\hline 1 & Pro-social behaviour & $x$ & $x$ & & & & & & & & & & & & & 02 & 14 \\
\hline 2 & Organization citizenship & & $x$ & & & & & & & & $x$ & & $x$ & & & 03 & 21 \\
\hline 3 & Task performance & & & $x$ & & & $x$ & & & & $x$ & & $x$ & $x$ & $x$ & 06 & 42 \\
\hline 4 & Interpersonally oriented & & & $x$ & & & & & & & & & & & & 01 & 07 \\
\hline 5 & Downtime behaviour & & & $x$ & & & & & & & & & & & & 01 & 07 \\
\hline 6 & Destructive behaviour & & & $x$ & & & & & & & & & & & & 01 & 07 \\
\hline 7 & Job specific task behaviour & & & & $x$ & & & & & & & & & $x$ & & 02 & 14 \\
\hline 8 & Non job specific behaviour & & & & $x$ & & & & & & & & & $x$ & & 02 & 14 \\
\hline 9 & Written and oral communication & & & & $x$ & & & & & & & & & $x$ & & 02 & 14 \\
\hline 10 & Demonstrating effort & & & & $x$ & & & & & & & & & $x$ & & 02 & 14 \\
\hline 11 & Personal discipline & & & & $x$ & & & & & & & & & $x$ & & 02 & 14 \\
\hline 12 & Peer and team performance & & & & $x$ & & & & & & & & & $x$ & & 02 & 14 \\
\hline 13 & Supervision or leadership & & & & $x$ & & & & & & & & & $x$ & & 02 & 14 \\
\hline 14 & Management/ administration & & & & $x$ & & & & & & & & & $x$ & & 02 & 14 \\
\hline 15 & In role work performance & & & & & $x$ & & & & & & & & & & 01 & 07 \\
\hline 16 & Extra-role behaviour & & & & & $x$ & & & & & & & & & & 01 & 07 \\
\hline 17 & Contextual Performance & & & & & & $x$ & $x$ & $x$ & & & & & $x$ & $x$ & 05 & 35 \\
\hline 18 & Generic work behaviour & & & & & & & & & $x$ & & & & & & 01 & 07 \\
\hline 19 & Adaptive work behaviour & & & & & & & & & & & $x$ & & $x$ & $x$ & 03 & 21 \\
\hline 20 & Counterproductive behaviour & & & & & & & & & & $x$ & & $x$ & & $x$ & 03 & 21 \\
\hline
\end{tabular}

(Source: based on literature)

*1. Brief and Motowidlo, (1986), 2. Organ (1988), 3. Murphy (1989), 4. Campbell et al. (1990), 5. Borman and Brush (1993), 6. Borman and Motowidlo (1993), 7. Motowidlo and Van Scotter (1994), 8. Borman and Motowidlo (1997), 9. Hunt (1996), 10. Viswesvaran and Ones (2000), 11. Pulakos et al. (2000), 12. Rotundo and Sackett (2002), 13. Stokes (2008), 14. Koopmans et al. (2011).

As a result of the discussion summary depicted in Table 1, up to year 2011 different types of job performance dimensions have been applied for measurement purpose. It shows that there is a remarkable trend and widely used dimensions have appeared. $42 \%$ of authors of the Table 1 consider that task performance is widely used dimension for measuring job performance and $35 \%$ of authors have used contextual performance as an important taxonomy. Other widely used job performance dimensions are adaptive and counterproductive work behaviour and citizenship behaviour. According to above evidences materialized from literature, task performance and contextual performance should be the most popularly used dimensions for measuring job performance. Furthermore, literature findings provide evidence that there are incalculable dimensions in literature for measuring job performance and some researchers have given different names for similar measures. Therefore, there is a possibility to amalgamate different dimensions in Table 1 subjected to reasonable evidences.

For example, "task performance", "job specific task behaviour" and "in role work performance" can be considered under the same category. Murphy (1989) elaborated task performance as "the accomplishment of tasks within an incumbent's job description". Williams and Anderson (1991) explained "in role work behaviour related to duties and responsibilities that are formally specified in the employment contract." Further, Campbell et al. (1990) measured job performance as prioritizing to the job specific task behaviour. They considered that job specific task behaviour as "a part of formal job of employee."

The other example is that "organizational citizenship behaviour", "extra-role behaviour", "non-job specific task behaviour" and "contextual behaviour" can be incorporated to the same category. Of course, Batman and Organ (1983) explains that the extra role behaviour which is not a part of the employees' formal job and this type of behaviour is called "organizational citizenship behaviour." Further, non-job specific behaviours do not pertain only to a particular job (Campbell et al., 1990). Motowidlo and Van Scotter (1994), Borman and Motowidlo (1997), Hattrup, O' Connell, and Wingate (1998) mentioned that abilities and skills tend to predict task performance while personality and related factors tend to predict contextual performance. 
Besides, "destructive or hazardous behaviour" of Murphy can be merged with the "counterproductive work behaviour". Of course, counter productive work behaviour relates to non-task negative consequences for organization as well as employees (Rotundo, 2002). Murphy (1989) provides the same meaning and explains "destructive work behaviour" compliance with rules, violence of job, theft and other behaviours counterproductive to the goals of the organization. As a result of the above review, taxonomies of job performance are reasonable to categorize generally into three such as task performance, contextual performance and counterproductive work behaviour.

\subsection{Dimensions of Job Performance Related to Specific Professions}

The above analytical part reviewed and prioritized the job performance domain for general usage. Following part of this paper is expected to review the taxonomies of job performance that have been used in recent studies for different professions representing service sector organizations. According to Chang and Chen (2006), Jung and Jung (2001) as cited in Sani et al. (2013), 'performance could be indicated by assessing employees' workload where the determination of workload plays an important role in designing and evaluating an existing man-machine system". The workload may not be similar in different occupational settings. Following empirical findings in Exhibit 2, show selected evidence for the synthesis of job performance used by researchers recently associating with the selected specific job positions including service sector employees.

Exhibit 2. Dimensions of job performance related to different professions

\begin{tabular}{|c|c|c|c|c|}
\hline Year & Author/s & Study topic & $\begin{array}{l}\text { Sample of the } \\
\text { study }\end{array}$ & Dimensions of job performance \\
\hline 2000 & Conway & $\begin{array}{l}\text { Managerial performance } \\
\text { development constructs and } \\
\text { personality correlates }\end{array}$ & $\begin{array}{l}2110 \text { Managers, } \\
\text { variety of industries }\end{array}$ & $\begin{array}{l}\text { 1. Interpersonal effectiveness } \\
\text { 2. Willingness to handle different situations } \\
\text { 3. Team work and personal adjustment } \\
\text { 4. Adaptability } \\
\text { 5. Leadership and development }\end{array}$ \\
\hline 2003 & $\begin{array}{l}\text { Rothmann, } \\
\text { Coetzer }\end{array}$ & $\begin{array}{l}\text { The big five personality } \\
\text { dimensions } \\
\text { performance }\end{array}$ & $\begin{array}{l}159 \text { employees of a } \\
\text { pharmaceutical } \\
\text { company }\end{array}$ & $\begin{array}{l}\text { 1. Task performance } \\
\text { 2. Creativity } \\
\text { 3. Managerial skills }\end{array}$ \\
\hline 2006 & $\begin{array}{l}\text { Vandaele, } \\
\text { Gemmel }\end{array}$ & $\begin{array}{l}\text { Performance implication of } \\
\text { in-role and extra-role behaviour }\end{array}$ & $\begin{array}{l}1174 \text { employees of } \\
\text { front retail service } \\
\text { employees }\end{array}$ & $\begin{array}{l}\text { 1. In-role performance } \\
\text { 2. Extra role performance towards customers } \\
\text { 3. Extra-role performance towards the } \\
\text { organization }\end{array}$ \\
\hline \multirow[t]{3}{*}{2007} & \multirow[t]{3}{*}{$\begin{array}{l}\text { Griffin, Neal, and } \\
\text { Parker }\end{array}$} & \multirow[t]{3}{*}{$\begin{array}{l}\text { A new model of work role } \\
\text { performance: positive } \\
\text { behaviour in uncertain and } \\
\text { interdependent contexts }\end{array}$} & \multirow[t]{3}{*}{$\begin{array}{lr}491 & \text { Supervisors } \\
\text { from } & 32 \\
\text { organizations }\end{array}$} & $\begin{array}{l}\text { 1. Individual task behaviours: } \\
\text { Task Proficiency, Task adaptability and Task } \\
\text { proactivity } \\
\text { 2. Team member behaviours: }\end{array}$ \\
\hline & & & & $\begin{array}{l}\text { Team member proficiency, Team member } \\
\text { adaptability and Team member proactivity } \\
\text { 3. Organization member behaviours: }\end{array}$ \\
\hline & & & & $\begin{array}{l}\text { Organizational member proficiency, } \\
\text { Organizational member adaptability and } \\
\text { Organizational member proactivity }\end{array}$ \\
\hline 2013 & Usop et al. & $\begin{array}{l}\text { Work performance and job } \\
\text { satisfaction among teachers }\end{array}$ & $\begin{array}{l}200 \text { Teachers, } \\
\text { division of Cotabato } \\
\text { city Philippines }\end{array}$ & $\begin{array}{l}\text { 1. Diversity of learners } \\
\text { 2. Curriculum content and pedagogy } \\
\text { 3. Planning, as sessing and reporting } \\
\text { 4. Learning environment } \\
\text { 5. Social regards for learning } \\
\text { 6. Community linkages } \\
\text { 7. Personal, social growth and professional } \\
\text { development }\end{array}$ \\
\hline 2014 & Shekari et al. & $\begin{array}{l}\text { Investigating the relationship } \\
\text { between quality of working life } \\
\text { and employees' performance }\end{array}$ & $\begin{array}{l}150 \text { Staff members } \\
\text { of water and waste } \\
\text { water office, } \\
\text { Khorasan, Razavi }\end{array}$ & Annual performance indicators \\
\hline 2014 & $\begin{array}{l}\text { Hettiararchchi, and } \\
\text { Jayarathna }\end{array}$ & $\begin{array}{l}\text { The effect of employee work } \\
\text { related attitudes on employees } \\
\text { job performance: tertiary and } \\
\text { vocational education sector in } \\
\text { Sri Lanka }\end{array}$ & $\begin{array}{l}323 \text { employees of } \\
\text { the technical } \\
\text { education and } \\
\text { vocational training }\end{array}$ & $\begin{array}{l}\text { 1.Trait based } \\
\text { 2. Behaviour based } \\
\text { 3. Results based }\end{array}$ \\
\hline 2015 & Muindi et al. & $\begin{array}{l}\text { Quality of work life, } \\
\text { personality, job satisfaction, } \\
\text { competence } \\
\text { performance of academic staff }\end{array}$ & $\begin{array}{l}365 \text { Academic staff } \\
\text { in Kenyan public } \\
\text { universities }\end{array}$ & $\begin{array}{l}\text { 1. Task performance including } \\
\text { Job - specific task performance } \\
\text { Non-job specific task performance } \\
\text { 2. Contextual performance including }\end{array}$ \\
\hline
\end{tabular}




\begin{tabular}{|c|c|c|c|c|}
\hline & & in public universities in Kenya & & $\begin{array}{l}\text { Effort } \\
\text { Personal discipline } \\
\text { Team work }\end{array}$ \\
\hline 2015 & Rai and Tripathi & $\begin{array}{l}\text { A study on quality of work life } \\
\text { and its effects on job } \\
\text { performance }\end{array}$ & $\begin{array}{l}253 \text { IT professionals } \\
\text { from middle level } \\
\text { cadre }\end{array}$ & $\begin{array}{l}\text { 1. Knowledge } \\
\text { 2. Skills } \\
\text { 3. Quality } \\
\text { 4. Accountability } \\
\end{array}$ \\
\hline 2015 & Hafeez and Akbar & $\begin{array}{l}\text { Impact of training on } \\
\text { employees performance }\end{array}$ & $\begin{array}{l}\text { Officers of } \\
\text { pharmaticulatic } \\
\text { companies, Pakistan }\end{array}$ & $\begin{array}{l}\text { 1. Demonstrating team work } \\
\text { 2. Communication skills } \\
\text { 3. Customer service } \\
\text { 4. Interpersonal relationship } \\
\text { 5. Absenteeism }\end{array}$ \\
\hline 2016 & Philippaers et al. & $\begin{array}{l}\text { Perceived employability in } \\
\text { relation to job performance: A } \\
\text { cross-lagged study accounting } \\
\text { for a negative Path via reduced } \\
\text { commitment }\end{array}$ & $\begin{array}{ll}791 & \text { Flemish } \\
\text { employees } & \end{array}$ & $\begin{array}{l}\text { 1. Task behaviour } \\
\text { 2. Helping behaviour } \\
\text { 3. Creative behavior }\end{array}$ \\
\hline
\end{tabular}

\section{(Source: based on literature)}

The above Exhibit 2 shows recent empirical findings of job performance measurement dimensions which have been used by different authors to measure job performance of different professions. Among them, there are managers, teachers, lecturers, IT professionals, office staff members, and retail employees. According to each profession, dimensions of job performance diverge. It is evident for multidimensional nature of job performance. On the other hand Exhibit 2 provides evidence for the customized nature of performance measures. Adding further, Austin and Villano va (1982), as cited in Welbourne et al. (1998) highlighted that lack of generalizability of the performance criteria hinders the validity of many predictors of job performance. Eventually, it can be noted that job performance is normally conceptualized as actions and behaviours that are under the control of the individual that contribute to the goals of the organization. Hence, dimensions may vary according to job tasks, work circumstances, personal traits, organizational environment etc.

\subsection{Importance of Job Performance}

It is indeed a critical organizational phenomenon owing to several value motives or reasons which are presented as follows:

i. Job performance is one of the most extensively researched phenomena.

ii. Job performance works as an outcome or a consequence of many variables in many of studies.

iii. Job performance can be considered as an intervening variable.

iv. Summation of individual performance makes organizational performance or business performance.

i. Job performance is one of the most extensively researched phenomena. There are lots of theoretical and empirical studies which have been conducted in relation to job performance. As evidence, this paper has reviewed many theoretical and empirical findings above in Table 1 and Exhibit 2. Furthermore, according to Arvey and Murphy (1998), Campbell (1990), Austin and Vilano va (1992), Schemidt and Hunter (1992), Murphy and Cle veland (1995), as cited in Viswesvaran (2001) job performance is an important 'Construct' in industrial or organizational psychology. Sonnentag and Frese (2001) conducted a desk research and found 146 research findings during the past 20 years. As a result, they found that $54.8 \%$ of literature sources considered individual level performance as a 'Core-construct'.

ii. Job performance works as an outcome or a consequence of many variables in many of studies. Schmidt and Hunter (1992) mentioned that Job performance is the most important 'Dependent Variable' in industrial work and organizational psychology. A desk research conducted by Sonnentag and Frese (2001) reveals that majority of the sample (72.5\%) addressed individual level performance as a 'Dependent variable' or 'Outcome measure'. As per researchers namely Beh (2011), Shekari et al. (2014), Hettiarachchi and Jayarathna (2014), Muindi et al. (2015), Rai and Tripathi (2015), Hafeez (2015), and Philippaers (2016) have conducted studies and measured job performance as a dependent variable.

iii. Job performance can be considered as an intervening variable. It means that there is a causal link between both individual perspective as well as the organizational level perspective. Accordingly, job performance should be linked with employee ability, traits, motivation, education, job knowledge and skills etc. Due to the variation of those factors, job performance may be varied by person to person. On the other hand it affects to the overall outcomes of the organization. It means that the consequences (results) of job performance are productivity, 
customer retention, customer satisfaction, growth of sales etc.

iv. Summation of individual performance makes organizational performance or business performance.

Individual performances determine the performance of the organization as a whole (Hitt et al., 1979). Sum of individual job performances in all departments of an organization will become organizational performance of that organization. Rounok and Parvin (2011) emphasized that skilled, qualified, and motivated workforce contributes a lot to achieve the organization's success. Hatane (2015) mentioned that organizational performance includes both financial and non-financial performance. Job performance is also considered under the subjective and objective forms or quantity and quantity forms. Hence, the overall individual performance directly relates to business performance. Newstrom and Davis (1997), shows the relationship between ability and organizational results emphasizing the importance of individual contribution to the organizational outcomes.

Exhibit 3. Individual contribution for organizational results

\begin{tabular}{llll}
\hline 1. & Knowledge $\mathrm{x}$ skill & & $=$ ability \\
2. & Attitude $\mathrm{x}$ situation & & $=$ motivation \\
3. & Ability $\mathrm{x}$ motivation & & $=$ potential human performance \\
4. & Potential performance $\mathrm{x}$ resources $\mathrm{x}$ opportunity & $=$ organizational results \\
\hline
\end{tabular}

(Source: Newstrom and Davis, 1997)

As a result of the above matters it is clear that the interaction among the individual characteristics and characteristics of the situation causes individual performance and it is the base for organizational results.

It is possible to mention here another motive for considering job performance as critical. Importance of job performance can also be presented when purposes of evaluation of job performance are considered. In organizations evaluation or appraisal of employee job performance is done at least once a year (Opatha, 1992). According to Opatha 2013, evaluation of employee job performance has a variety of utility and serves as a summative function (to assist in making equitable and effective personal decisions such as salary increments, incentives, transfers and disciplinary actions); a formative function (to improve employee current and future performance by identifying strengths and weaknesses and accordingly by training and developing); and an informative function (a communication to the employee dealing with upward and downward communication for self-motivation and self-development).

Moreover, Cascio (1991) categorized the purposes of job performance into three; including 1.administrative purposes to the organization, 2.Feedback purpose to the individuals and 3.Research purpose for deciding validation of selection techniques or efficacy of training etc. DeVries et al. (1986), as cited in Viswesvaran (2001), noted that the uses of job performance assessment in Great Britain can be categorized into three; 1 . To improve current performance, 2.To set objectives, and 3. To identify training and de velopment needs. As per, Viswesvaran (2001) reviewed the results of different researchers and noted "in 1970 in both United States and the United Kingdom indicated the prevalence of the job performance assessment for the purpose of making administrative decisions". The above findings show supportive evidences towards the different usages of job performance results.

With reference to the above, it is clear that job performance is a more important construct on behalf of employee perspective as well as employer perspective. Hence, it is worth to create our working definition for job performance as follows.

"Job performance is the extent to which the employee has shown his or her traits, engaged in behaviours and produced results which are appropriate to task performance, and has engaged in citizenship performance and counterproductive performance during a particular period of time."

As a result interaction of individual characteristics and characteristics of the situation, employees may behave differently. Hence, traits and employee behaviours are more sensible for job performance. On the other hand, it is needed to consider how individuals contribute towards the organization. It means that measures should be linked with output of individuals' work. Accordingly, employee behaviour that directly contributes to producing goods or services is labeled as 'Task performance' and employee behaviour that helps others and creates a positive work environment is labeled as 'Citizenship performance' and harmful employee behaviour that is labeled as 'Counterproductive performance'.

\section{Conclusion}

Every organization performs its task with the help of its resources. Among the resources manpower is the live resource that utilizes other non-living resources for maximum level of output. The human resource is critical and difficult to manage because human behaviour is highly unpredictable. It differs not only from individual to 
individual but also on the part of same individual at different points of time. In spite of biological and cultural similarities, human beings not only differ in their appearance but also in their capabilities and competencies based on their living background, training, experiences and personal qualities etc. With the aim of reviewing literature of job performance, this paper focused on six objectives. The first objective was to define job performance according to different authors. They were careful to define job performance based on job, job tasks, personal qualities and existing circumstances. Secondly, the paper discussed the dynamic nature of the concept of job performance and reviewed both personal and system factors which may affect its dynamic nature. Thirdly, this paper reviewed different taxonomies of job performance in chronological order and it is concluded that job performance is a multidimensional concept. As a result, the selected twenty dimensions of job performance were compared among selected authors and these dimensions were summarized based on their usage. Hence, the forth objective was achieved having found widely used job performance dimensions that are task performance and contextual performance based on literature comparison. As the fifth objective, recently used dimensions of measuring job performance were found from recent empirical findings that have been done in service sector related organizations. It reviews that researchers have unquestionably used different dimensions for measuring job performance for different professions based on their requirements. Finally we reviewed that there are numbers of specific dimensions which have been categorized yet, researchers face difficulties in applying clear-cut measurement dimensions. Though this study is a desk research, it reviewed well the construct of job performance, dimensions and did a comparison among the researchers and created the working definition for job performance and suggested more appropriate measurement dimensions for measuring job performance. Further, empirical findings were reviewed based on different occupations in service sector organizations. It is also discussed four motives under the importance of job performance adding no velty to the existing literature. Finally, we recommend that empirical studies must be done specially for job performance of diverse employee work groups in diverse careers associating with service sector in different organizations in different countries.

\section{References}

Barrick, M. R., \& Mount, M. K. (1993).Autonomy as a moderator of the relationships between the Big Five personality dimensions and job performance.Journal of applied Psychology,78(1), 111. https://doi.org/10.1037/0021-9010.78.1.111

Bass, A. R., \& Turner, J. N. (1973). Ethnic group differences in relationships among criteria of job performance. Journal of Applied Psychology, 57(2), 101. https://doi.org/10.1037/h0037125

Bateman, T. S., \& Organ, D. W. (1983). Job satisfaction and the good soldier: The relationship between affect and employee "citizenship". Academy of management Journal, 26(4), 587-595. https://doi.org/10.2307/255908

Beh, L. S. (2011). Challenges of quality of work life: Evidence and implications in developed and developing countries.

Benardin, H. J., \& Russell, J. E. (1993).Human Resource management; An Experiential Approach, (2 ${ }^{\text {nd }}$ ed.).

Bernardin, H. J., \& Beatty, R. W. (1984). Performance Appraisal: Assessing Human Behavior at Work (Kent, Boston: MA).

Borman, W. C., \& Brush, D. H. (1993). More progress toward a taxonomy of managerial performance requirements. Human performance, 6(1), 1-21. https://doi.org/10.1207/s15327043hup0601_1

Borman, W. C., \& Motowidlo, S. J. (1997). Task performance and contextual performance: The meaning for personnel selection research. Human performance, 10(2), 99-109. https://doi.org/10.1207/s15327043hup1002_3

Borman, W. C., \& Motowidlo, S. M. (1993).Expanding the criterion domain to include elements of contextual performance. Personnel Selection in Organizations; San Francisco: Jossey-Bass, 71.

Brief, A. P., \& Motowidlo, S. J. (1986). Prosocial organizational behaviors. Academy of management Review, 11(4), 710-725.

Brown, S. P. (1996). A meta-analysis and review of organizational research on job involvement.

Campbell, J. P., McHenry, J. J., \& Wise, L. L. (1990). Modeling job performance in a population of jobs. Personnel Psychology, 43(2), 313-575. https://doi.org/10.1111/j.1744-6570.1990.tb01561.x

Campbell, J. P. (1990). Modeling the performance prediction problem in industrial and organizational psychology. In: Dunnette MD, Hough LM, eds. 
Cascio, W. F. (1991), Applied Psychology in personnel Management, $4^{\text {th }}$ edition, Englewood, NJ: Prentice Hall.

Conway, J. M. (2000). Managerial performance development constructs and personality correlates. Human Performance, 13(1), 23-46. https://doi.org/10.1207/S15327043HUP1301_2

Griffin, M. A., Neal, A., \& Parker, S. K. (2007). A new model of work role performance: Positive behavior in uncertain and interdependent contexts. Academy of management journal,50(2), 327-347. https://doi.org/10.5465/AMJ.2007.24634438

Hackman, J. R., \& Oldham, G. R. (1976). Motivation through the design of work: Test of a theory. Organizational behavior and human performance, 16(2), 250-279. https://doi.org/10.1016/0030-5073(76)90016-7

Hafeez, U., \& Akbar, W. (2015). "Impact of Training on Employees Performance"(Evidence from Pharmaceutical Companies in Karachi, Pakistan). Business Management and Strategy, 6(1), 49-64. https://doi.org/10.5296/bms.v6i1.7804

Hatane, S. E. (2015). Employee satisfaction and performance as intervening variables of learning organization on financial performance. Procedia-Social and Behavioral Sciences, 211, 619-628. https://doi.org/10.1016/j.sbspro.2015.11.081

Hattrup, K., O'Connell, M. S., \& Wingate, P. H. (1998). Prediction of multidimensional criteria: Distinguishing task and contextual performance. Human Performance, 11(4), 305-319. https://doi.org/10.1207/s15327043hup1104_1

Hazzi, O. A., \& Maldaon, I. S. (2012). Prosocial organizational behaviors: The lifeline of organizations. European Journal of Economics, Finance and Administrative Sciences, 54, 106-114.

Hettiararchchi, H. A. H., \& Jayarathna, S. M. D. Y. (2014). The effect of Employee Work Related Attitudes on Employee Job Performance: AStudy of Tertiary and Vocational Education Sector in Sri Lanka.

Hitt, M. A., Mathis, R. L., \& Middlemist, R. D. (1979). Effective management. West Publishing Company.

Howard, A. (1995). The changing nature of work, San Frsnsisco, Jossy-Bass.

Hunt, S. T. (1996). Generic work behavior: An investigation into the dimensions of entry - level, hourly job performance. Personnel Psychology, 49(1), 51-83. https://doi.org/10.1111/j.1744-6570.1996.tb01791.x

Hunter, J. E. (1986). Cognitive ability, cognitive aptitudes, job knowledge, and job performance. Journal of vocational behavior, 29(3), 340-362. https://doi.org/10.1016/0001-8791(86)90013-8

Ilgen, D. R., \& Pulakos, E. D. (1999). The changing nature of performance: Implication for staffing, motivation and development. San Francisco: Jossey-Bass.

Johnson, E. C., \& Meade, A. W. (2010). A Multi-Level Investigation of Overall Job Performance Ratings. Paper presented at the 25th Annual Meeting of the Society for Industrial and Organizational Psychology, Atlanta, GA.

Koopmans, L., Bernaards, C.M., Hildebrandt, V. H., Schaufeli, W. B., De Vet, H. C. W., \& Vander Beek, A. J. (2011). Conceptual frameworks of individual work performance - A systematic review. Journal of Occupational and Environmental Medicine, 53(8), 856-866. https://doi.org/10.1097/JOM.0b013e318226a763

Landy, F. J., \& Farr, J. L. (1983). The measurement of work performance: Methods, theory, and applications. Academic Press.

Lawler, E. E., Mohrman, S. A., \& Ledford, G. E. (1992). Employee involvement and total quality management: Practices and results in Fortune 1000 companies. Jossey-Bass Inc Pub.

Motowidlo, S. J., \& Van Scotter, J. R. (1994).Evidence that task performance should be distinguished from contextual performance. Journal of Applied psychology, 79(4), 475.

https://doi.org/10.1037/0021-9010.79.4.475

Muindi, F., \& K'Obonyo, P. (2015). Quality of Work Life, Personality, Job Satisfaction, Competance, and Job Performance: ACritical review of Literature . European Scientific Journal, 11(26).

Murphy, K. R. (1989). Dimensions of job performance. Teting: Applied and Theoretical Perspective, 218-247. New York: Praeger.

Murphy, P. R., \& Jackson, S. E. (1999). Managing work role performance: Challenges for twenty-first century 
organizations and their employees. Pulakos (Eds.), The changing nature of performance: Implications for staffing, motivation, and development, 325-365.

Neal, A. F., \& Hesketh, B. (1999).Technology and performance. In D. Ilgen and D. Pulakos (Ed.), The Changing Nature of performance: Implications for Staffing, Motivation and Development (pp. 21-55) San Francisco: Jossey-Bass.

Newstrom, J. W., \& Davis, K. (1997).Organizational Behaviour: Human Behaviour of Work, New Dilhi: Tata McGraw-Hill Publishing company Ltd.

Opatha, H. H. D. N. P. (2015). Organizational Behavior: The Human Side of Work, Department of Human Resource Management, University of Sri Jayewardenapura, Sri Lanka.

Opatha, H. H. D. N. P. (1992). An Assessment of Employee Performance Appraisal Practices of Selected State Corporations in Sri Lanka. Vidyodaya Journal of Social Science, 6(1,2), 113-128.

Opatha, H. H. D. N. P. (2013). Towards a Sound Performance Appraisal System: An Agenda for Action. Sri Lankan Journal of Human Resource Management, 4(1), 62-77. https://doi.org/10.4038/sljhrm.v4i1.5620

Organ, D. W. (1988). Organizational citizenship behavior: The good soldier syndrome. Lexington Books/DC Heath and Com.

Otley, D. (1999). Performance management: a framework for management control systems research. Management Accounting Research, 10, 363-382. https://doi.org/10.1006/mare.1999.0115

Philippaers, K., De Cuyper, N., Forrier, A., Vander Elst, T., \& De Witte, H. (2016). Perceived employability in relation to job performance: A cross-lagged study accounting for a negative path via reduced commitment. Scandinavian Journal of Work and Organizational Psychology, 1(1).

Porter, L. W., \& Lawler, E. E. (1974).The effect of performance on job satisfaction. Studies in Personal and Industrial Psychology. Third Edition, Illinois.

Pulakos, E. D., Arad, S., Donovan, M. A., \& Plamondon, K. E. (2000). Adaptability in the workplace: development of a taxonomy of adaptive performance. Journal of applied psychology,85(4), 612. https://doi.org/10.1037/0021-9010.85.4.612

Pushpakumari, M. D. (2008). The Impact of Job Satisfaction on Job Performance: An Empirical Analysis. Meijo Review, 9(1), 89-105.

Rai, R., \& Tripathi, S. (2015). A Study on QWL and its effects on Job Performance. Journal of Management Scieces and Technology, 2(2), 33-42.

Rothe, H. F. (1951). Output rates among chocolate dippers. Journal of Applied Psychology,35(2), 94. https://doi.org/10.1037/h0055106

Rothe, H. F., \& Nye, C. T. (1961). Output rates among machine operators: III. A non-incentive situation in two levels of business activity. Journal of Applied Psychology, 45(1), 50. https://doi.org/10.1037/h0043367

Rothmann, S., \& Coetzer, E. P. (2003). The Big Five Personality Dimensions and Job Performance. Journal of Industrial Psychology, 29(1), 68-74. https://doi.org/10.4102/sajip.v29i1.88

Rotundo, M., \& Sackett, P. R. (2002). The relative importance of task, citizenship, and counterproductive performance to global ratings of job performance: a policy-capturing approach. Journal of applied psychology, 87(1), 66. https://doi.org/10.1037/0021-9010.87.1.66

Rounok, N., \& Parvin, M. M. (2011). Fostering Employee Performance: ALiterature Review.

Sani, J. A., Dawal, M., Zawiah, S., Zakwan, N. M., \& Mohideen Batcha, M. F. (2013). Measuring human performance of Malaysian train drivers: developing model using PLS approach.

Schmidt, F. L., \& Hunter, J. E. (1992). Development of a causal model of processes determining job performance. Current Directions in Psychological Science, 1(3), 89-92. https://doi.org/10.1111/1467-8721.ep10768758

Sekaran, U., \& Bougie, R. (2013). Research method for business: Askill Building Approach. New York

Shekari, G., Monshizadeh, M., \& Ansari, M. (2014). Investigating the relationship between quality of working life (based on Walton's model) and employees' performance (based on annual performance evaluation scores) in Water and Wastewater Office, KhorasanRazavi. http://journal-archieves36.webs.com/254-268may14.pdf 
Smith, P. C. (1976). Behaviors, results, and organizational effectiveness: The problem of criteria. Handbook of Industrial and organizational psychology, 745-775.

Sonnentag, S., \& Frese, M. (2001). Performance Concepts and Performance Theory: Chapter 01, Psychological Management and Individual Performance, John Wiley \& Sons Ltd.

Stewardt, G. L., \& Brown, K. G. (2009). HRM: Linking Strategy to Practice, John Wiley \& Sons, New York.

Stokes, C. K. (2008). Adaptive performance: An examination of convergent and predictive validity (Doctoral dissertation, Wright State University).

Toops, H. A. (1944). The Criterion, Education and Psychological Measurnment, 4, 271-297. https://doi.org/10.1177/001316444400400402

Tranfield, D., Denyer, D., \& Smart, P. (2003). Towards a methodology for developing evidence - informed management knowledge by means of systematic review. British Journal of Management, 14(3), 207-222. https://doi.org/10.1111/1467-8551.00375

Usop, A. M., Askandar, D. K., Langguyuan-Kadtong, M., \& Usop, D. A. S. O. (2013). Work Performance and Job Satisfaction among Teachers. International Journal of Humanities and Social Science, 3(5), 245-252.

Van Dyne, L., \& LePine, J. A. (1998). Helping and voice extra-role behaviors: Evidence of construct and predictive validity. Academy of Managementjournal, 41(1), 108-119. https://doi.org/10.2307/256902

Vandaele, D., \& Gemmel, P. (2006). Performance implications of in-role and extra-role behavior of frontline service employees (No. 06/411). Ghent University, Faculty of Economics and Business Administration.

Viswesvaran, C. (2001). Assessment of Individual Job Performance: A Review of Past Century and a Look Ahead, Handbook of Industrial, Work \& Organizational Psychology, 110- 126.

Viswesvaran, C., \& Ones, D. S. (2000).Perspectives on models of job performance. International Journal of Selection and Assessment, 8(4), 216-226. https://doi.org/10.1111/1468-2389.00151

Viswesvaran, C., Ones, D. S., \& Schmidt, F. L. (1996). Comparative analysis of the reliability of job performance ratings. Journal of Applied Psychology, 81(5), 557-574. https://doi.org/10.1037/0021-9010.81.5.557

Waldman, D. A. (1994). The contributions of total quality management to a theory of work performance. Academy of Management review, 19(3), 510-536.

Welbourne, T. M., Johnson, D. E., \& Erez, A. (1998). The role-based performance scale: Validity analysis of a theory-based measure. Academy of management journal, 41(5), 540-555. https://doi.org/10.2307/256941

Williams, L. J., \& Anderson, S. E. (1991).Job satisfaction and organizational commitment as predictors of organizational citizenship and in-role behaviors. Journal of management,17(3), 601-617. https://doi.org/10.1177/014920639101700305

\section{Copyrights}

Copyright for this article is retained by the author(s), with first publication rights granted to the journal.

This is an open-access article distributed under the terms and conditions of the Creative Commons Attribution license (http://creativecommons.org/licenses/by/4.0/). 